MARCIN KONARSKI

Wyższa Szkoła Menedżerska w Warszawie

\title{
KWESTIONOWANIE LEGITYMACJI PRAWA JAKO FORMA OCHRONY GODNOŚCI CZŁOWIEKA I OBYWATELA
}

Treść: Wstęp. - 1. Prawo do oporu. - 2. Obywatelskie nieposłuszeństwo. - 3. Rewolucja. - Zakończenie.

\section{Wstęp}

Na wstępie niniejszych rozważań Czytelnikowi należy się kluczowe wyjaśnienie. Otóż zwrot „godności człowieka i obywatela” użyty w tytule niniejszych rozważań oznacza w zamyśle autora element będący artefaktem instytucji o jakich przyjdzie poniżej mówić. Jest tak bowiem pojęcie „prawa człowieka” niejednokrotnie powiązane z legalnym systemem zabezpieczającym ewentualne roszczenia za ich naruszenie. W przypadku zaś niejako naruszenia „godności” człowieka, jako osoby ludzkiej, i jako obywatela będącego symbolem poszanowania niezbywalnych praw natury rzeczy, częstokroć nie sposób w inny sposób dochodzić jednostce rozumnej krzywd doznanych od wykonujących swoje rządy w sposób uwłaczający celowi prawa i jego poszanowaniu poprzez stosowanie zgodnie $\mathrm{z}$ wolą ludu wyrażaną $\mathrm{m}$. in. w wyborach politycznych. Częstokroć w odpowiedzi na naruszanie przez organy państwa godności człowieka poprzez naruszanie jego praw obywatelskich mają miejsce zachowania będące formami indywidualnego lub grupowego „protestu” sumienia przeciwko podważaniu i naruszaniu powszechnej w danej kulturze lub subkulturze natury rzeczy. 
Nikt raczej nie będzie starał się podważyć tezy, że wszystkim ludziom przysługuje godność z tytułu uprzywilejowanego miejsca człowieka w przyrodzie, bowiem o godności człowieka decyduje wyposażenie go, i tylko jego w duszę nieśmiertelną, w możność organizowania własnych popędów przez rozum, a także kształtowanie własnego istnienia według uznanej przez siebie hierarchii wartości ${ }^{1}$. Należy zauważyć, że pojęcie godności bywa wiązane z pojęciem osobowości. Osobowość jest w pewnym stopniu niezależna od fizycznego „ja” człowieka, bowiem nie kończy się ona ze śmiercią, trwa tak długo, jak długo się o zmarłym pamięta. Jak podnosi Maria Ossowska „sprzęgnięcie naszego 'ja' fizycznego z osobowością tłumaczy to, że żądamy szacunku dla ciał zmarłych, potępiamy 'bezczeszczenie' zwłok" 2 . Dodatkowym elementem jest gotowość obrony uznanych przez siebie wartości, gotowość poświęcenia czegoś dla ich zachowania ${ }^{3}$. W przypadku znaczenia pojęcia osoby, należy podkreślić, że łacińskie słowo persona stanowiło odpowiednik greckiego prosopon. Termin ten oznaczał „maskę”, „rolę”, „funkcję”, czyli owa maska odpowiadała roli, jaką się odgrywa, czy funkcji, jaką się spełnia, które z kolei decydowały o naszej godności (w sensie prestiżu) ${ }^{4}$. Z kolei zawarta w tytule niniejszej analizy „godność obywatelska” rozumiana jest tutaj jako ogół praw ujmowanych na przełomie XVIII i XIX wieku w Deklaracjach prawa (Stany Zjednoczone, Francja) włączanych do ustaw konstytucyjnych. Pojęcie godności obywatelskiej pokrywa się zatem tutaj z koncepcjami idei praw obywatelskich, których ochrona w przypadku pogwałcenia przez daną formę rządu, częstokroć pociąga za sobą naruszenie aktualnego porządku prawnego w imię wartości oczywiście wyższych niż te, które zobowiązują obywateli

\footnotetext{
${ }^{1}$ Zob. M. Ossowska, Normy moralne. Próba systematyzacji, Warszawa 1985, s. 58 .

${ }^{2}$ TAMŻE, s. 58.

${ }^{3}$ Por. C. Horn, Naruszalna i nienaruszalna godność ludzka: próba wyjaśnienia, Przegląd Filozoficzno - Literacki 2012, nr 1-2, s. 19 i n.

${ }^{4}$ M. Ossowska, dz. cyt., s. 68-69.
} 
do posłuchu względem władzy ${ }^{5}$. Zarówno więc pojęcie godności człowieka, jak i pojęcie godności obywatelskiej są w pojęciami szerszymi niż pojęcie praw człowieka i obywatela bowiem te stanowią jedynie urzeczywistnienie tych „godności” w sposób zapewniający ich sądową ochronę ${ }^{6}$.

Z pewnością kwestionowanie wiążących wzorów zachowania jakimi są normy prawne powszechnie obowiązujące nigdy nie może być traktowane jedynie w kategoriach sankcji przewidzianych za ich podważenie. Przecież można śmiało powiedzieć, że już wniesienie środka zaskarżenia - na przykład orzeczenia sądowego w sprawie cywilnej - stanowi przejaw kwestionowania autorytetu prawa, tutaj w postaci formalnego wniosku o wzruszenie decyzji organu wymiaru sprawiedliwości, a przecież nie wiąże się ono z negatywnymi skutkami dla wnoszącego, poza oczywiście jakimś prawdopodobieństwem nieuwzględnienia naszego środka odwoławczego ${ }^{7}$. Rzecz jasna zagadnienia jakie będą stanowiły przedmiot niniejszych rozważań dotyczą tematyki związanej z kwestionowaniem legitymacji prawa z punktu widzenia raczej prawa konstytucyjnego niż sądowych metod dochodzenia swoich uprawnień. Wiązać się one będą przede wszystkim z pozycją jednostki w państwie i możliwościami kształtowania przez obywateli porządku prawno - państwowego w radykalnych

\footnotetext{
${ }^{5}$ Jak pisał Herbert SPencer, system sprawiedliwości powinien być oparty na uznaniu praw osobistych istniejących poza wszelką powagą prawną, tenże, Jednostka wobec państwa, Warszawa 2002, s. 164.

${ }^{6}$ Irena Lipowicz twierdzi, że godność jest właściwa z samego „urodzenia”, od początku życia do jego zakończenia i nie ma nic wspólnego ze statusem cywilnym, obywatelstwem, majątkiem czy wykształceniem, a poza tym jest podstawą innych praw i inne prawa nie mogą jej „przeważyć”, tenże, Godność ludzka w świetle prawa administracyjnego, Przegląd Filozoficzno - Literacki 2012, nr 1-2, s. 101.

${ }^{7}$ W ocenie MieczysŁawa Sawczuka, tylko tam, gdzie istnieje określone remedium, podstawowe prawa człowieka mogą istnieć naprawdę, bo mają ochronę, zob. tenże, Naruszenie podstawowych prawa człowieka (na przykładzie prawa do wysłuchania), w: H. Zięba - Załucka (red.), Prawa i wolności obywatelskie w procesie transformacji ustrojowej. Materiały z Międzynarodowej Konferencji Naukowej (Sieniawa 22-23 kwietnia 1996), Rzeszów 1997, s. 40.
} 
niekiedy formach, które przyjęto nazywać formami kwestionowania legitymacji prawa.

Hugo Grocjusz, nazywany nie bez racji twórcą współczesnego prawa międzynarodowego, którego prace znane są na całym świecie, a zaliczany do twórców szkoły prawa naturalnego twierdził, że treść podstawowych zasad prawa naturalnego wypływa $\mathrm{z}$ rozumnej natury ludzkiej i jest niezmienna. Podobnie twierdzili w starożytności stoicy. Uważali oni, że prawo naturalne ze swej istoty spoczywa na pojęciu powszechnego rozumu wszechnatury (koinos logos) ${ }^{8}$. Grocjusz uważał, że prawo naturalne obowiązuje, nawet przy hipotetycznym założeniu, że Bóg nie istnieje (hipotesa etiamsi daremus non esse Deum) ${ }^{9}$. Wyróżniał on trzy następujące rodzaje prawa: prawo naturalne (ius naturale) i prawo pozytywne (ius voluntarium). Prawo pozytywne dzielił na pozytywne prawo boskie (ius divinum voluntarium) i pozytywne prawo ludzkie (ius humanum voluntarium), zaś to na prawo cywilne (ius civile) i prawo międzynarodowe (ius gentium) ${ }^{10}$.

Nie wdając się w rozważania, co do trafności podziału przedstawionego przez Grocjusza, najważniejszy wydaje się być dla poniższych rozważań fakt, że łączył on ideę prawa naturalnego z koncepcją państwa przy pomocy idei umowy społecznej, suwerennej władzy i prawa do oporu. Prawo do oporu będące jedną $\mathrm{z}$ form kwestionowania legitymacji prawa, o których będą traktowały niniejsze rozważania Grocjusz co prawda uznawał, jednakże ponad nim stawiał pokój i bezpieczeństwo państwa ${ }^{11}$.

Z kolei przecież nie bez znaczenia dla dalszej analizy pozostaje to właśnie odwołanie się do koncepcji Grocjusza bowiem mając na uwadze potencjalne skutki, jakie za sobą niosą wszelkie formy powszechnego kwestionowania legitymacji prawa, można obawiać się analizując przykłady, jakie dostarcza historia i współczesność, że częstokroć pokój i bezpieczeństwo państwa schodzą na dalszy

\footnotetext{
${ }^{8}$ A. Kość, Podstawy filozofii prawa, Lublin 1998, s. 39.

${ }^{9}$ Tamże, s. 53.

${ }^{10}$ Tamże, s. 53.

${ }^{11}$ Tamże, s. 54.
} 
plan wobec celów, jakie przyświecają wewnętrznym grupom społecznym kwestionującym aktualny w danym momencie system prawno - państwowy.

Bez większych trudności większości ludziom na świecie nie sposób byłoby nie zgodzić się z tezą, że prawa człowieka mają charakter uniwersalny ${ }^{12}$. Posiadają je wszyscy ludzie żyjący we wszystkich społecznościach z racji godności osoby ludzkiej uznanej za podstawową wydaje się zasadę prawa przyjętą przez narody cywilizowane. Jak pisze Jacek Breczko, „przypominają (...) aksjomaty w geometrii; przyjmuje się je bez dowodu jako coś podstawowego"13. Wydaje się, to bardzo trafne porównanie, które można odczytać ostatecznie, jak wspomnę na końcu niniejszych rozważań, jako wynikające z natury rzeczy, jako ostatniej, najwyższej instancji odwoławczej w wielu przypadkach.

Prawa człowieka i sformalizowany system ich międzynarodowej ochrony, jaki znany jest nam współcześnie powstał po II wojnie światowej w wyniku zorganizowanej współpracy państw - członków powstałej w 1945 roku, w odpowiedzi na tragiczne doświadczenia powszechnej wojny, Organizacji Narodów Zjednoczonych.

Na międzynarodowy system praw człowieka i ich ochrony składają się zarówno instytucje gwarantujące realne środki tworzące system kontroli monitorowania i przestrzegania, jak i akty prawa międzynarodowego o powszechnym zasięgu wśród których można wymienić chociażby Kartę Narodów Zjednoczonych i zawartą w niej zasadę poszanowania praw człowieka, Powszechną Deklarację Praw Człowieka z 10 grudnia 1948 roku, Międzynarodowe Pakty Praw Człowieka z 1966 roku i wiele innych dotyczących ochrony poszczególnych grup społecznych. Wszystkie one mają na celu poszanowanie w stosunkach międzynarodowych i prawodawstwach poszczególnych państw podstawowych zasad prawa człowieka, które można interpretować

\footnotetext{
${ }^{12} \mathrm{Na}$ temat uzasadnienia podstawowych praw człowieka, zob. M. SAwCZUK, Naruszenie prawa do wystuchania podstawa skargi konstytucyjnej, Annales Universitatis Mariae Curie-Skłodowska vol. XLIV, Sectio G, 1997, s. 97 i n.

${ }^{13}$ J. BR eczko, Wprowadzenie, w: M. Konarski, M. Wielec, M. Woch (red.), Prawa człowieka w państwie, Warszawa 2014, s. 17.
} 
najprościej, za art. 38 Statutu Międzynarodowego Trybunału Sprawiedliwości z siedzibą w Hadze, jako ogólne zasady prawa uznane przez narody cywilizowane ${ }^{14}$.

Prawa człowieka więc jako system przyrodzonych i wynikających z natury rzeczy instytucji prawnych mających chronić godność osoby ludzkiej swoim zasięgiem wydają się niekiedy legitymizować zachowania kwestionujące legitymację prawa i stawiając niejednokrotnie Arystotelesowską słuszność ponad sprawiedliwością ${ }^{15}$, za którą tutaj można by przyjąć zachowania nie podważające mocy wiążącej norm prawnych w żadnych okolicznościach, czyli nawet w przypadku powszechnego przeświadczenia o ich szkodliwości. Z pewnością formy kwestionowania legitymacji prawa, które stanowić będą przedmiot rozważań mogą być uznane jako instytucje prawne mające na celu ochronę poszanowania godności obywatelskiej poprzez wyrażenie swojej woli najczęściej w masowym ruchu społecznym mającym na celu częstokroć legalnie wybrane organy władzy zwierzchniej.

Zagadnienia stanowiące przedmiot poniższej refleksji o charakterze akademickim mogą być oczywiście rozpatrywane z pozycji różnych nauk. Żywe zainteresowanie nimi odnajdziemy chociażby na gruncie historiozofii, historii politycznej i gospodarczej, nauk o polityce i wielu innych. Nas oczywiście interesują one najbardziej jako przedmiot badań nauki prawa. Zarówno prawo do oporu, obywatelskie nieposłuszeństwo i rewolucja jako formy kwestionowania legitymacji prawa nie są dostatecznie opisane w nauce prawa i stanowią one ten obszar badawczy, na który niewielu przedstawicieli jurysprudencji ma odwagę wstąpić. Zazwyczaj zagadnienia te podnoszone są w nauce prawa konstytucyjnego jednakże w sposób jak się wydaje zdecydowanie niedostateczny. Problemy związane z kwestionowaniem legitymacji prawa od wieków stanowiły również przedmiot zainteresowania filozofii prawa i głównie tam odnaleźć możemy zarówno

\footnotetext{
${ }^{14}$ Zob. A. Przy borowska - Klimczak, Prawo międzynarodowe publiczne. Wybór dokumentów, Lublin 1998, s. 41.

${ }^{15}$ Por. A. Kość, dz. cyt., s. 194-198.
} 
pytania i odpowiedzi odnoszące się do mocy wiążącej prawa jako systemu norm zachowania o szczególnym znaczeniu ${ }^{16}$.

Poniższe rozważania mają jedynie na celu wskazanie podstawowych tez z jakimi borykać przyjdzie się współczesnemu badaczowi tych zjawisk społeczno - prawnych. Po wtóre, niniejsze refleksje naukowe dotyczące form kwestionowania legitymacji prawa stanowią asumpt do dalszych badań w tym zakresie, które z pewnością powinny być prowadzone ze względu na ich doniosłość i charakter oraz znaczenie $\mathrm{w}$ kontekście problemów społeczno - prawnych z jakimi mamy do czynienia w czasach nam współczesnych.

\section{Prawo do oporu}

Z całą pewnością pod pojęciem prawa do oporu jako jednej z form kwestionowania legitymacji prawa kryją się bardzo różnorodne sytuacje polityczne. Jeśli władza, co podkreślał Jan Baszkiewicz, gwałci porządek prawny swoimi despotycznymi i arbitralnymi aktami, opór wobec niej jest obroną naruszonego prawa i daje się ująć w pozytywnoprawne kryteria ${ }^{17}$. W przypadku jednak, gdy władza zdegenerowała

\footnotetext{
${ }^{16}$ A. Kość, dz. cyt., s. 232-241; por. M. Sawczuk, M. Konarski, B. Nowaczyński, W poszukiwaniu mocy wiążącej prawa, w: Abiit non obiit. Księga poświęcona pamięci Księdza Profesora Antoniego Kościa, A. Dębiński, P. Stanisz, T. Barankiewicz, J. Potrzeszcz, W. Sz. Staszewski, A. Szarek - Zwijacz, M. Wójcik (red.), Lublin 2013, s. 317-354.

${ }^{17} \mathrm{~J}$. BAszKIEw ICZ, Z zagadnień nowożytnej koncepcji prawa do oporu, w: J. Baszkiewicz, Państwo. Rewolucja. Kultura polityczna, Poznań 2009, s. 621. Według Herberta L.A. Harta wyrażenie pozytywizm w odniesieniu do kryteriów prawnych używane jest na oznaczenie jednego lub kilku następujących poglądów: 1) że prawa są rozkazami ludzi; 2) że nie istnieje żaden konieczny związek pomiędzy prawem a moralnością czy też prawem takim, jakie jest, i prawem takim, jakie być powinno; 3) że analiza czy też badanie znaczeń pojęć prawnych jest czymś nadzwyczaj ważnym i musi być odróżnione od badań historycznych, socjologicznych oraz krytycznej oceny prawa z punktu widzenia moralności, celów społecznych, funkcji itp.; 4) że system prawa jest „zamkniętym systemem logicznym”, a poprawne decyzje $\mathrm{w}$ jego ramach mogą być wydedukowane $\mathrm{z}$ uprzednio ustalonych reguł prawnych przez wyłączne odwołanie się do logiki; 5) że przekonania moralne nie mogą być dowodzone w taki sposób, jak stwierdzenia o faktach, tzn. za pomocą racjonalnej
} 
porządek prawny w całości lub przynajmniej w części, zmieniając go w system bezprawia, taki opór przeciw uciskowi oznacza zakwestionowanie porządku prawnego i wymyka się kryteriom pozytywnoprawnym, a więc wymaga poszukiwania podstaw w prawie bożym lub naturalnym, zasadach sprawiedliwości i słuszności społecznej ${ }^{18}$.

Prawo do oporu może mieć różny charakter. Może ono mieć bowiem charakter represyjny (na przykład kara za złe rządzenie), jak również może ono mieć charakter defensywny (jako obrona zbiorowości przed złym rządem). Poza tym prawo do oporu przeciw szeroko rozumianemu uciskowi może być realizowane albo poprzez działanie zbiorowe (np. rewolucja) albo może wyrażać się w oporze indywidualnym ${ }^{19}$.

Prawo do oporu niekiedy ujmowane było jako teza, która zakładała, iż posłuszeństwo należy się tylko takiej władzy, która zapewniała protekcję przed przemocą ze strony tych, którzy naruszają ustalony w umowie społecznej, porządek prawny. Kiedy takiej protekcji zabrakłoby, poddani mogliby sami bronić swoich praw i odmawiać posłuszeństwa bezsilnej władzy, co najdobitniej wyraził Thomas Hobbes, pisząc, że celem i kresem posłuszeństwa poddanych jest skuteczność państwowej ochrony.

Niczym innym, jak właśnie prawem do oporu były przecież w szlacheckiej Polsce postanowienia zawarte w artykułach henrykowskich, które przewidywały, że jeżeli król nie będzie przestrzegał praw i przywilejów szlachty, będzie ona mogła wypowiedzieć mu posłuszeństwo. O doniosłym znaczeniu tego postanowienia świadczy fakt, że od 1576 roku articulus de non praestanda oboedienta wszedł do przysięgi

argumentacji, doświadczenia lub dowodu, H. L.A. Ha rT, Pojęcie prawa, Warszawa 1998, s. 399.

${ }^{18} \mathrm{~J}$. BASZKIEWICZ, dz. cyt., s. 621-622.

${ }^{19}$ TAMżE, s. 622. Opór indywidualny wyrażał się często w oporze stanowiącym czyny crimen maiestatis. Katalog tych czynów obejmował dwie grupy czynów stanowiących crimen maiestatis: pierwsza obejmuje działania na szkodę państwa, druga - zamachy przeciw panującemu, zob. M. Dyjakowska, Subsydiarne stosowanie prawa rzymskiego w Polsce przedrozbiorowej na przykładzie zbrodni obrazy majestatu, w: Teka Komisji Prawniczej-OL PAN 2012, Lublin 2012, s. 62. 
koronacyjnej królów polskich ${ }^{20}$. Wypowiedzenie posłuszeństwa królowi przyjmowało zazwyczaj formę rokoszu, czyli w XVII-XVIII wieku konfederację nie uznaną przez króla. Konfederacje opierające swoją legitymację na artykule o wypowiedzeniu posłuszeństwa w uznaniu historyków prawa stanowiły przede wszystkim ważny element korygujący wady ustroju i aktywizujący szlachtę, a co więcej konfederacje uważane były jako przejaw szlacheckiej demokracji bezpośredniej ${ }^{21}$. Jednakże, jak podaje Aleksandra Barwicka, kodyfikacje sejmów z 1607 i 1609 roku w Polsce wprowadzały niezwykle skomplikowaną procedurę egzekucji prawa do oporu, polegającą na trzykrotnym upomnieniu króla, najpierw przez prymasa, następnie przez prymasa i senatorów, na końcu przez sejm, co praktycznie uniemożliwiło przeciwstawienie się władcy na drodze legalnej ${ }^{22}$. Konsekwencjami uznania za tyrana i wypowiedzenie posłuszeństwa mogły być między innymi: kara boża, cezury kościelne (klątwa-anatema, interdykt), zwolnienie z posłuszeństwa, depozycja-wygnanie itp. ${ }^{23}$

Wracając natomiast do rozważań Hobbesa należy zauważyć, że mimo, iż Hobbes uważany jest za zdecydowanego wroga wszelkiego oporu wobec suwerennej władzy, to jednak, niekiedy dopuszczał on taki czynny opór, w szczególności w obronie życia, zdrowia i osobistej wolności jednostek. Thomas Hobbes dopuszczał poza tym samoobronę zbiorową, a nawet samoobronę przysługującą przestępcy. Mamy tutaj więc do czynienia z opozycją praw jednostki i praw rządu, bowiem ostatecznie prawo do kolektywnej samoobrony otwiera drogę do legalizacji buntu ${ }^{24}$, bowiem „opozycjoniści zawsze mogą się powołać

\footnotetext{
${ }^{20}$ Zob. J. Bardach, B. LeŚnOdorski, M. Pietrzak, Historia ustroju i prawa polskiego, Warszawa 1996, s. 217.

${ }^{21}$ Zob. TAMŻE, s. 226.

${ }^{22}$ A. BARWICKA, Prawo do oporu w świetle silva rerum z okresu po rokoszu Lubomirskiego, w: M. Markiewicz, E. Opaliński, R. Skowron (red.), Król a prawo stanów do oporu, Kraków 2010, s. 404.

${ }^{23}$ Zob. R. Совотка, Opór władcom w świetle Roczników Jana Długosza, w: M. Markiewicz, E. Opaliński, R. Skowron (red.), dz. cyt., s. 385-389.

${ }^{24}$ J. BASZKIEWICZ, dz. cyt., s. 624.
} 
na takie prawo do samoobrony zbiorowej, gdy suweren zechce poddać karze ich działania przeciwko rządowi"25.

Historia oporu przeciwko prawu ma swój wielowiekowy rodowód, i poza wspomnianym już Hobbesem, liczni przed nim, i wielu po nim myślicieli zajmował w sposób szczególny ten problem ${ }^{26}$. Nie sposób w tym miejscu rzecz jasna odnieść się do tych wszystkich koncepcji, wobec czego odsyłamy w tej mierze do artykułu autorstwa Jerzego Oniszczuka, w którym analizuje on szeroko te zagadnienia ${ }^{27}$. W dalszej części naszych rozważań skupimy się przede wszystkim na prawie do oporu, tak jak je sformułowano w czasach rewolucji francuskiej, odwołując się do postanowień, najpierw Deklaracji Praw Człowieka i Obywatela z 1791 roku (artykuł II stanowił, iż celem każdej organizacji politycznej jest utrzymanie naturalnych i nie przedawnionych praw człowieka, wymieniając wśród nich obok wolności, własności i bezpieczeństwa, właśnie opór przeciwko uciskowi), a następnie Deklaracji Praw Człowieka i Obywatela poprzedzającej ustawę konstytucyjną roku 1793 (tzw. konstytucję jakobińską), przede wszystkim

\footnotetext{
${ }^{25}$ TAMŻE, s. 624.

${ }^{26}$ Jak pisał przed laty Konstanty Grzybowski, „prawo do oporu ma swą genezę w ustroju średniowiecznym, swą rozbudowę teoretyczną w doktrynach monarchomachów w XVI w. swój renesans w Rewolucji amerykańskiej ale wszędzie tam występuje na plan pierwszy prawo oporu społeczności przeciw władcy, wszędzie tam pozostaje to prawo przede wszystkim w związku z dualistyczną konstrukcją państwa (władca - stany, rządzący - poddani reprezentowani przez swe organy). Dopiero w deklaracjach francuskich odrywa się ono zupełnie zarówno od dualistycznej konstrukcji państwa, jak i od teoretycznego ujęcia jako prawa społeczeństwa (czyli stanów) i technicznego ujęcia w określone formy, staje się świętym, niepozbywalnym, w żadne formy nie ujętym prawem każdej jednostki.(...) staje się jako dogmat siłą stojącą ponad wszelkim prawem pozytywnym”, K. Grzy воwsкi, Demokracja francuska, Kraków 1947, s. 24-25.

${ }^{27}$ J. Oniszczuk, Prawo do oporu i Radbrucha wizja niepostuszeństwa obywateli. Opór jako odtworzenie nowoczesnej polis, w: Nieprzeciętność. Dylemat wolności, M. Szyszkowska, A. Rossmanith (red.), Warszawa 2013, s. 21-33. Mimo, że autor analizuje prawo do oporu głównie z punktu widzenia koncepcji G. Radbrucha, to jednak przytacza na wskazanym przez nas stronach również koncepcje m.in.: Tomasza z Akwinu, Ockhama, Bodina, Calvina, Brutusa, Grocjusza, Locke’a, Fichtego, Milla.
} 
z tego względu, że bodajże po raz pierwszy w dziejach nowożytnego państwa pojęcie prawa do oporu znalazło swoje umocowanie w najwyższym rangą akcie normatywnym w państwie ${ }^{28}$. Na kontynencie amerykańskim z kolei o prawie do oporu przeczytamy w Deklaracji Niepodległości z 4 lipca 1776 roku. Uznano już na wstępie Deklaracji, że ilekroć jaka forma rządu zaczyna gwałcić te zasady (prawo do życia, prawo do wolności i prawo do poszukiwania szczęścia), naród ma prawo do jej zmiany lub zniesienia i do ustanowienia nowego rządu, opartego na takich podstawach i organizującego swe władze w takiej formie, jaka wydawać się będzie najbardziej właściwa dla zapewnienia bezpieczeństwa i szczęśliwości.

Wróćmy jednak w naszych rozważaniach na kontynent europejski, do ogarniętej rewolucyjnym wrzeniem Francji. Jakobini twierdzili, że opór przeciwko uciskowi wynika $\mathrm{z}$ innych praw człowieka, a gdy rząd gwałci prawa ludu, powstanie jest dla ludu i dla każdej części ludu najświętszym prawem, a zarazem najpilniejszym obowiązkiem ${ }^{29}$. Tak ostatecznie sformułowany zapis jakobińskiej Deklaracji Praw

\footnotetext{
${ }^{28}$ Stanisław Ehrlich stał na stanowisku, podobnie jak wcześniej przywołany K. Grzybowski, że zagadnienie prawa do oporu sięga wieków średnich przytaczając jako przykład przyczyny uchwalenia w Anglii Wielkiej Karty Swobód będącej wyrazem politycznego kompromisu ze stawiającym opór stanem szlacheckim $\mathrm{z}$ arystokracją na czele. Autor ten uważa ten moment dziejowy za początek procesu, który doprowadził do uformowania się państwa praworządnego, zob. S. EHRLICH, Wiążace wzory zachowania. Rzecz o wielości systemów norm, Warszawa 1995, s. 197. Jak pisał z kolei Iwo Jaworski dla przestrzegania postanowień Wielkiej Karty Swobód przewidziano daleko idące sankcje bowiem baronowie posiadali możliwość dzięki wybranym spośród siebie dwudziestu pięciu przedstawicielom, czuwania czy król przestrzega przyjętych zobowiązań. W razie zaś ich złamania mieli oni prawo wezwać do czynnego oporu przeciwko niemu jednakże opór ten miał się odbywać z zachowaniem nietykalności osoby króla i jego rodziny i ustać $\mathrm{z}$ chwilą naprawienia przez władcę nadużyć, I. JAworski, Zarys powszechnej historii państwa i prawa, Warszawa 1996, s. 157-158. Jak podaje Benedykt Zientara rada baronów nigdy się nie zebrała, B. Zientara, Historia powszechna średniowiecza, Warszawa 1994, s. 205.

${ }^{29}$ M. ScZANIECKI, Wybór źródeł do historii państwa i prawa $w$ dobie nowożytnej, Warszawa 1996, s. 147-148.
} 
Człowieka i Obywatela zrodził się z głębokiej debaty, jaka miała miejsce wśród przywódców rewolucji. Po pierwsze prawo do oporu przeciw uciskowi, a więc przeciw stosowanej przemocy nie może być podporządkowany jakimś legalnym formom, które z kolei są umieszczone w ramach legalizmu, bowiem jak mówił sam Maksymilian Robespierre, gdy pojawiają się prawa opresyjne, wtedy lud nie może czekać na uruchomienie jakiejś legalnej procedury ${ }^{30}$. Takie podejście oczywiście, jak zaznacza J. Baszkiewicz, kwestionowało art. VII Deklaracji Praw z 1789 roku, gdzie była mowa o tym, że nie wolno opierać się zastosowaniu ustawy, bowiem skoro ustawa jest wyrazem volonte generale, to nie może być represyjna ${ }^{31}$. Inną kwestią było rozróżnienie prawa do oporu przeciw ustawom represyjnym (a więc również takim, które zakładały stosowanie przemocy wobec ludności) i prawem do petycji (reklamacji) przeciw ustawom niepożytecznym. Rozwiązanie tej kwestii oparło się ostatecznie na tym, iż lud ma prawo krytykować złe ustawy, a następnie powstawać przeciw ustawom opresyjnym, czyli jeśli owa krytyka nie odniesie zakładanego skutku².

Projekt Deklaracji Praw, w wersji przygotowanej przez M. Robespierre’a przyniósł, najpełniejsze i najdalej idące rozwinięcie idei prawa do oporu, którą zacieśniła jakobińska Deklaracja Praw z 24 czerwca 1793 r., zgodnie z którą: 1) opór przeciwko uciskowi wynika z innych praw człowieka (art. 33); 2) całe społeczeństwo doznaje ucisku, gdy jeden z jego członków jest uciskany, zaś każdy z członków społeczeństwa doznaje ucisku, gdy rozciąga się on na całe

\footnotetext{
${ }^{30} \mathrm{Na}$ posiedzeniu jakobinów w dniu 29 lipca 1792 roku Robespierre mówił, iż „państwo musi być ocalone w każdy możliwy sposób; niekonstytucyjne jest tylko to, co zmierza do jego ruiny", J. BAszkiewicz, Maksymilian Robespierre, Wrocław 1989, s. 139. A. Manfred, historyk zajmujący się badaniem dziejów Francji pisał, że Robespierre w tych lipcowych dniach „rysuje program odważnego i zdecydowanego zburzenia całego organizmu państwowo - politycznego", J. BAszkiewicz, Rousseau, Mirabeau, Robespierre. Trzy portrety z epoki Wielkiej Rewolucji Francuskiej, Warszawa 1988, s. 339.

${ }^{31}$ J. BASZKiewicz, Z zagadnień nowożytnej..., s. 631.

${ }^{32}$ TAMŻE, s. 631.
} 
społeczeństwo (art. 34);3) gdy rząd gwałci prawa ludu, powstanie jest dla ludu i dla każdej części ludu najświętszym prawem, a zarazem najpilniejszym obowiązkiem (art.35) ${ }^{33}$. Jest tutaj więc mowa o stawianiu oporu przeciw aktom władzy, naruszającym treść ustawy lub przepisane przez nią formy, zaś sam respekt dla ustawy zabrania poddać się takim arbitralnym aktom, a jeśli władza stosuje w takim przypadku siłę, to wtedy można na nią odpowiedzieć również siłą, co nazwać można „oporem w obronie praw” ${ }^{34}$. Z kolei z postanowienia art. 35 wynika raczej „opór przeciw prawom”, czyli zdegenerowanemu, opresyjnemu porządkowi prawnemu. Przeciw takim zaś opresyjnym prawom opór ludu odwołuje się do podstawowych praw naturalnych ${ }^{35}$. Mimo, że późniejszy przewrót termidoriański zniweczył dzieło jakobinów i pominął problem prawa do oporu, to z pewnością idea zaufania do ludu (do jego cierpliwości, do jego łagodności, jak i tego przekonania, iż powstaje on przeciwko prawom jedynie w słusznej sprawie), jaką prezentowali jakobini odbiła się szerokim echem w całej Europie i wywarła niebagatelny wpływ na kształtowanie się praw człowieka w czasach nam już współczesnych.

Istotnym dla naszych rozważań będzie przytoczenie tutaj również refleksji Gustava Radbrucha (jego poglądy szerzej przytaczamy w dalszej części pracy), który pisał o tym, że naród nie jest zobowiązany służyć, a prawnicy muszą zdobyć się na odwagę, aby pozbawić ustawy niezgodne z prawem naturalnym, charakteru prawnego, bowiem kryterium kierującym ludzi ku właściwej decyzji, tym, co umożliwia przecięcie swoistego napięcia między obowiązkiem posłuszeństwa władzy i zasadą prawno naturalną (sprawiedliwości) jest sumienie człowieka $^{36}$.

\footnotetext{
${ }^{33}$ M. Sczaniecki, dz. cyt., s. 147-148.

${ }^{34}$ J. BAsZKiewiCZ, Z zagadnień nowożytnej..., s. 632.

${ }^{35}$ TAMŻE, s. 632.

${ }^{36}$ J. OniszczuK, dz. cyt., s. 34. Por. J. ZaJADŁo, Formuła Radbrucha, Gdańsk 2001, s. 105 i n.; F. Donough, Opposition and resistance in Nazi Germany, Cambridge 2005, s. 40 i n.; R. Dworkin, Imperium prawa, Warszawa 2006, s. 105 - 108.
} 


\section{Obywatelskie nieposłuszeństwo}

Można postawić tezę, że inną formą prawa do oporu (bowiem było ono odmiennie uwarunkowane historycznie), posiadająca swoiste znamiona, jest obywatelskie nieposłuszeństwo (civil disobedience), występujące również pod nazwą konfliktu bez przemocy (non - violence). Jak podkreślał Stanisław Ehrlich, „obywatelskie nieposłuszeństwo powstało i rozwinęło się poza europejskim kręgiem kulturowym. Dopiero po latach dzieło i praktyka Mahatmy Ghandiego stały się znane i przeniknęły do Europy i Ameryki (zwłaszcza do Stanów Zjednoczonych, gdzie Martin Luther King kontynuował je dostosowując do potrzeb walki z dyskryminacją czarnoskórych Amerykanów)" ${ }^{\prime 37}$.

Cywilne nieposłuszeństwo można określić jako „publiczny, pozbawiony przymusu, świadomy i polityczny akt godzący w prawo (contrary to law), podjęty zazwyczaj w celu wywołania zmiany prawa lub zmiany polityki rządu"38, przy czym można zaproponować trzy kryteria pozwalające odróżnić obywatelskie nieposłuszeństwo od innych form sprzeciwu: 1) nie jest to ani protest, ani rada; 2) nie jest to rewolucja, ponieważ ta dąży do obalenia przemocą podstaw ustrojowych społeczeństwa; 3) obywatel odmawiający posłuszeństwa nie powinien być traktowany jako przestępca, ponieważ motywem jego zachowania nie jest osobista korzyśśc ${ }^{39}$.

\footnotetext{
${ }^{37}$ S. EHRLiCH, Norma, grupa, organizacja, Warszawa 1998, s. 180; por. V. HAKsAR, The Right To Civil Disobedience, Osgoode Hall Journal 2003, vol. 41, s. 407 i n., gdzie autor ten odwołując się do tez M. Ghandiego określa cywilne nieposłuszeństwo jako najczystszy typ konstytucyjnej agitacji.

${ }^{38}$ S. EHRLICH, Norma..., s. 180.

${ }^{39}$ Tamże, s. 180. Zob. S. R. Schlesinger, Civil Disobedience: The Problem of Selective Obedience to Law, Hastings Constitutional Law Quarterly 1976, vol. 3, s. 947 i n., gdzie autor ten pisze: „civil disobedience is illegal activity undertaken to protest laws that are regarded as unjust. It is characterized by open, nonclandestine, violation of the law being protested or of other laws", ibidem, s. 947; A. SA BL, Looking Forward to Justice: Rawlsian Civil Disobedience and its Non-Rawlsian Lessons, The Journal of Political Philosophy 2001, vol. 9, s. 307 i n.; L. M. Sidman, On Constitutional Disobedience, Georgetown Public Law and Legal Research Paper 2012, no. 12, s. 1-32.
} 
Ronald Dworkin pisząc o nieposłuszeństwo obywatelskim podkreśla, że obywatel winien jest posłuszeństwo prawu, a nie czyjejkolwiek interpretacji prawa, przy czym nie postępuje nieuczciwie co do zasady, jeśli kieruje się własnym świadomym i przemyślanym, rozeznaniem tego, czego prawo wymaga ${ }^{40}$. I tutaj pojawia się kolejny podstawowy element źródeł nieposłuszeństwa. Wydaje się, że tkwi on w sądach moralnych w rozumieniu ich z punktu widzenia tzw. społecznego modelu intuicyjnego, którego główna teza zakłada, sąd moralny to uznanie czynu bądź postawy jakiejś osoby (grupy osób) za dobrą lub złą, w kontekście wartości uznawanych w danej kulturze czy subkulturze za pożądane ${ }^{41}$. O nieformalnej słuszności wspominał Immanuel Kant pisząc, że najściślejsze prawo bywa największym bezprawiem ale temu złu nie da się zaradzić na drodze prawnej, mimo iż dotyczy ono roszczenia prawnego. Takie roszczenie zdaniem Kanta może rozpatrzyć jedynie trybunał sumienia (forum poli), podczas gdy każda kwestia dotycząca tego, co dyktowane prawem musi być rozstrzygana przez prawo obywatelskie (forum soli) ${ }^{42}$.

Z kolei Robert Alexy analizując ocenę aktu cywilnego nieposłuszeństwa, tzn. czy ma charakter cywilnego nieposłuszeństwa, uzależniał go od: 1) nieegoistycznych pobudek działającego (zmiana w interesie publicznym); 2) ukierunkowania działania przeciwko prawu rażąco niezgodnemu z podstawowymi regułami moralności, czy racjonalności; 3) publicznego charakteru i działania bez przemocy; 4) wyczerpania drogi prawnej; 5) zgody na poniesienie kary; 6) spełniania reguły mniejszego $\mathrm{zła}^{43}$. Natomiast $\mathrm{w}$ przypadku instytucji urzędowego odstępstwa od prawa, wymaga się, aby to postępowanie nastąpiło: 1) ze względu na rażącą niezgodność z moralnością lub racjonalnością; 2) było dokonywane $\mathrm{w}$ interesie publicznym $\mathrm{w}$ myśl zasady mniejszego zła; 3) przy aprobacie opinii publicznej.

\footnotetext{
${ }^{40}$ Zob. R. Dworkin, Biorac prawa poważnie, Warszawa 1998, s. 385.

${ }^{41}$ Zob. B. BRożeK, Normatywność prawa, Warszawa 2012, s. 231-232.

${ }^{42}$ Zob. I. Kant, Metafizyczne podstawy nauki prawa, Kęty 2006, s. 47.

${ }^{43}$ J. OniszcZuk, dz. cyt., s. 33-34.
} 
Obywatelskie nieposłuszeństwo tak więc to nic innego jak forma protestu (sprzeciwu) ${ }^{44}$, w której protestujący mają świadomość naruszania prawa ${ }^{45}$. Jest czym innym od rewolucji ${ }^{46}$. Jak podkreśla J. Oniszczuk, „prowadzący obywatelski opór, zasadniczo nie prowadzą tego $\mathrm{w}$ formie zaburzeń społecznych, a nadto akceptują podleganie prawnej odpowiedzialności. Istotą jest cel tego nieposłuszeństwa, albowiem chodzi np. o upublicznienie wiedzy o niesprawiedliwym prawie, odwołanie się do świadomości społecznej (...) Dlatego też istotna ma być tutaj motywacja tego oporu, jego uzasadnienie. Uważa się, że motyw nie może wynikać z interesu indywidualnego (prywatnego), ale winien sięgać do dobra wspólnego (powszechnego)" ${ }^{\prime 7}$. $\mathrm{Z}$ pewnością każda $\mathrm{z}$ takich cech obywatelskiego nieposłuszeństwa, jak symboliczne, intencjonalne złamanie prawa, jawność, brak przemocy, niepodważanie porządku prawnego jako całości, gotowość

\footnotetext{
${ }^{44}$ Protest jako podstawowa forma przeciwdziałania (obok nacisku) realizuje się jako przeciwmobilizacja wobec istniejącej struktury panowania. Protest staje się najskuteczniejszy w osiąganiu celów, gdy państwo, w które mierzy, samo jest już słabe. W przypadku, gdy nacisk wywierany na państwo zakłada próbę wpływania i lobbowania dla osiągnięcia oczekiwanego wyniku wywodzącą się z wnętrza systemu politycznego, protest pociąga za sobą podjęcie rywalizacji bądź doprowadzenia do próby sił, która podważa istniejącą strukturę panowania i dąży w pewien sposób do jej przeformowania. Protest znajduje najskuteczniejszy wyraz w formie zbiorowego działania organizacji i ruchów społecznych, J. Sсотт, Władza, Warszawa 2006, s. 38-39 i 139.

${ }^{45}$ J. Oniszczuk, dz. cyt., s. 34.

${ }^{46}$ C. Cohen, Civil Disobedience and The Law, Rutgers Law Review 1966, vol. 21, s. 3. Jak podkreśla ten autor „revolution seeks the overthrow of constituted authority, or at least repudiates that authority in some sphere; civil disobedience does neither. The civil disobedient accepts, while the revolutionary rejects, the frame of established authority and the general legitimacy of the system of laws", tamże, s. 3.

${ }^{47}$ J. Oniszczuk, dz. cyt., s. 35. J. Oniszczuk odwołuje się w swoich refleksjach do poglądów Henry'ego D. Thoreau, który główne tezy zawarł w swoim najsłynniejszym dziele: On The Duty OfCivil Disobedience, www.ibiblio.org/ebooks/Thoreau/ Civil\%20Disobedience.pdf
} 
poddania się sankcjom prawnym, jak pisze Michał R. Kaczmarczyk, wzmacnia efekt demonstracji funkcjonalnej ${ }^{48}$.

Wśród wielu przykładów obywatelskiego nieposłuszeństwa jako formy protestu na uwagę zasługują te z nich, które miały miejsce w czasach komunistycznych rządów w Polsce po drugiej wojnie światowej. Jako przykład podaje się zazwyczaj protesty robotnicze, które poczynając od czerwca 1956 r. do schyłku PRL-u stanowiły nieodłączny element kształtowania się ruchów społeczno - opozycyjnych mających na celu doprowadzenie do zmian ustrojowych w Polsce. Jednakże poza protestami o ściśle politycznym znaczeniu na uwagę zasługują protesty społeczne skierowane przede wszystkim przeciwko poszczególnym inicjatywom władz komunistycznych, takim jak np. budowa Elektrowni Jądrowej Żarnowiec ${ }^{49}$. W tym ostatnim przypadku protesty społeczne okazały się na tyle skuteczne, że stanowiły przyczynę zamknięcia budowy.

W okresie komunistycznych rządów w Polsce po II wojnie światowej wśród wielu ruchów społecznych organizujących protesty społeczne warto przypomnieć powstały w $1985 \mathrm{roku}$, w odpowiedzi na represje władz wobec osób odmawiających z przyczyn sumienia służby w armii PRL, Ruch „Wolność i Pokój”, którego działania skierowane były na ochronę praw człowieka i ochronę środowiska pod koniec lat 80 -tych dwudziestego wieku w Polsce. Ten ruch społeczny organizował m.in. debaty, akcje ulotkowe, pikiety, marsze, wiece, demonstracje, manifestacje, blokady, okupacje budynków.

\section{Rewolucja}

Robert von Mohl, twórca nowożytnej koncepcji państwa prawnego, twierdził, iż rewolucja może być dozwolona w przypadku, „gdy już po wyczerpaniu wszelkich organizacją wskazanych środków (...) po bezprawnym odebraniu tychże gwałtem nie zostaje dopuszczone

\footnotetext{
${ }^{48}$ Zob. M.R. KaCZmarczyк, Nieposłuszeństwo obywatelskie a pojęcie prawa, Warszawa 2010, s. 309.

${ }^{49} \mathrm{~J}$. WALuszko, Protesty przeciwko budowie Elektrowni Jądrowej Żarnowiec w latach 1985 - 1990, Gdańsk 2013, s. 36-63.
} 
zaprowadzenie jakiegoś urządzenia uważanego przez ogół narodu za nieodzowne do zadowolenia nowego w życiu jego kierunku. Wyraźnie bowiem tutaj przysługuje narodowi prawo ostateczności, to zaś tym niewątpliwsze, im o wyższe cele życia ludzkiego chodzi”"50. Oznacza to, że państwo, które w swoich działaniach nie realizuje misji powierzonej przez naród, a polegającej na urzeczywistnianiu celów jego życia, nie ma prawa bytu. Za niemoralne i nielegalne mogą być tylko uznane takie gwałtowne wywroty, które w ocenie $R$. $v$. Mohla rozpoczęte były bez dostatecznego usprawiedliwienia (z powodu „mało" ważnych w ogólnym odczuciu społecznym „zażaleń” w stosunku do rządu) ${ }^{51}$.

Spróbujmy przyjrzeć się bardziej szczegółowo pojęciu rewolucji. Otóż możemy stwierdzić, że zachowania rewolucyjne jako formy kwestionowania legitymacji prawa mają zdecydowanie inny wymiar niż te przedstawione przez nas powyżej bowiem kwestionują one cały funkcjonujący system polityczny zmierzając w ostatecznym efekcie do zawładnięcia ośrodkiem decyzji politycznej w państwie ${ }^{52}$. Pojęcie rewolucji pochodzące od łacińskiego terminu "revolutio” oznacza „obrót” lub „przewrót” i było ono używane pierwotnie w naukach przyrodniczych. Na gruncie nauk społecznych pojęcie to jest rozumiane wieloznacznie przez co na potrzeby naszych dociekań przyjmijmy, iż oznacza ono szybkie i zbrojne zawładnięcie, przy szerokim poparciu mas materialnie upośledzonych, ośrodka decyzji politycznej w państwie przez zorganizowane grupy czy polityczne partie, które ten ośrodek poprzednio jawnie lub konspiracyjnie zwalczały ${ }^{53}$. W przeciwieństwie do rewolucji takie sytuacje społeczno - polityczne jak pucz, zamach stanu, przewrót, rewolta itp. nie dają początku nowemu ustrojowi społeczno - politycznemu, a prowadzą jedynie do

\footnotetext{
${ }^{50}$ R. v. MoHL, Encyklopedia umiejętności politycznych, Warszawa 2003, s. 151.

${ }^{51}$ TAMŻE, s. 153.

${ }^{52}$ S. Ehrlich, Wiążące..., s. 203.

${ }^{53}$ TAMŻE, s. 204.
} 
zmian personalnych w ośrodku decyzji politycznej ewentualnie do ograniczonych reform $w$ ramach istniejącego systemu ${ }^{54}$.

Jak pisał przed laty Harold J. Berman, każda rewolucja jest świadectwem upadku starego systemu prawnego, co więcej zaś „,w każdej $\mathrm{z}$ wielkich rewolucji dostrzec można okres przejściowy, w którym jedne prawa szybko zastępowano nowymi, a te nowe równie szybko odwoływano, znoszono lub zastępowano kolejnymi. Ostatecznie jednak każda z nich w swym toku przywracała prawa przedrewolucyjne, reaktywowała wiele $\mathrm{z}$ ich elementów, włączając je w nowy system odzwierciedlający cele, wartości i przekonania, w imię których przeprowadzano rewolucję"55.

Zakwestionowanie legitymacji politycznego ośrodka decyzji przy jednoczesnym zakwestionowaniu legitymacji decyzji normatywnych ustanowionych przez niego zawsze od wieków szła w parze z przedstawieniem przez rewolucjonistów własnego systemu wartości i opartego na nim systemu prawa pozytywnego ${ }^{56}$.

Jak przyjmuje się w literaturze przedmiotu okresy gwałtownych przewrotów czyli rewolucji mimo że częstokroć odmienne w swoim charakterze odznaczają się pewnymi prawidłowościami, przy czym znaczenie owej „gwałtowności” nie oznacza siły przymusu prawnego stosowanego przez rządy za pośrednictwem policji czy armii, lecz oznacza siłę pozaprawną używaną przez jednostki czy grupy

\footnotetext{
${ }^{54}$ TAmżE, s. 205. Bertrand de Jouvenel pisał, że „prawdziwą historyczną funkcją rewolucji jest odnowienie i umocnienie władzy", B. DE Jouvenel, Traktat o władzy, Warszawa 2013, s. 246.

${ }^{55}$ H.J. Berman, Prawo i rewolucja. Ksztattowanie się zachodniej tradycji prawnej, Warszawa 1995, s. 43.

${ }^{56}$ Robespierre w przeddzień zakończenia prac Konstytuanty powiedział, że „rewolucja nie jest niczym innym, jak sumą wysiłków Narodu, zmierzających do zachowania lub do zdobycia Wolności", J. BAszkiewicz, Francuzi 1789 - 1794. Studium świadomości rewolucyjnej, Warszawa 1989, s. 280.
} 
przeciwko istniejącej władzy ${ }^{57}$. Ci, którzy dochodzili ostatecznie w wyniku takich działań do władzy, tworzyli nowy system prawny ${ }^{58}$.

Wspominane prawidłowości dotyczące rewolucji oznaczają, że każda z nich była zasadniczą, szybką, gwałtowną i trwałą zmianą systemu społecznego jako całości. Poza tym każda z nich szukała legitymizacji w prawie fundamentalnym, w odległej przeszłości oraz w apokaliptycznej wizji przyszłości. Co więcej, wynikiem każdej rewolucji był nowy system prawny ucieleśniający główne cele rewolucji i modyfikujący zachodnią tradycję prawną jednakże żaden ostatecznie jednak nie wykraczał poza tę tradycję ${ }^{59}$.

Pamiętać należy, że typologia rewolucji może określać je za pomocą różnych kryteriów takich jak: znaczenie historyczne (husycka, purytańska, niepodległościowa, narodowa, komunistyczna), cel (rewolucje personalne, konstytucyjne, socjalne, religijne, gospodarcze), charakter sił dokonujących rewolucji (rewolucje wojskowe, parlamentarne, masowe), paradygmatu charakteryzującego dany typ rewolucji (żakierie, rebelie, zbrojne insurekcje - powstania), czy wreszcie kryterium klasowego (rewolucje niewolników, antyfeudalne, proletariackie) ${ }^{60}$. Ostatecznie jednak, bez względu na przyjęty typ klasyfikacji, rewolucja wiąże się bezwzględnie ze zmianą ustroju państwa niosącym za sobą szereg modyfikacji o charakterze prawno - instytucjonalnym, które podważają zastany porządek prawny i legitymację norm zachowania o cechach powszechnie obowiązujących na terenie danej społeczności państwowej. Każda rewolucja, jak pisał Jan Baszkiewicz, jest procesem burzenia i adaptowania, każda coś przeobraża i coś kontynuuje z materii społecznej zastanej ${ }^{61}$.

\footnotetext{
${ }^{57}$ H.J. Berman, dz. cyt., s. 34.

${ }^{58}$ Jak stwierdza H.J. Berman „system rządzenia i prawo każdego kraju zachodniego wywodzi się z takiej rewolucji”, H.J. BERMAN, dz. cyt., s. 34 .

${ }^{59}$ H.J. Berman, dz. cyt., s. 33.

${ }^{60}$ M. Chmaj, M. Żmigrodzki, Wprowadzenie do teorii polityki, Lublin 1996, s. $213-215$.

${ }^{61}$ J. BAszKiewicz, Ciagłość i zmiana w kulturze politycznej okresu rewolucji: przykład rewolucji francuskiej, w: J. Baszkiewicz, Państwo. Rewolucja. Kultura..., dz. cyt., s. 683.
} 


\section{Zakończenie}

Z całą pewnością analiza dokonana powyżej odnosi się jedynie do kilku wybranych przez autora form kwestionowania legitymacji prawa. Powodem są tutaj zarówno wąskie ramy wypowiedzi, jak i ogrom materiału badawczego, którego ilość przekracza możliwości analizy w tym miejscu.

Problem legitymacji prawa i jej kwestionowania należy bodaj do najstarszych, z którymi wielu już filozofów i jurystów starało się zmierzyć na przestrzeni wielu wieków. Zapewne dopóki ludzkość będzie trwała, problem ten pozostanie nierozwiązany, co rzecz jasna nie zwalnia z obowiązku dociekania tej materii przez rzetelnego naukowca.

Przed laty, Antoni Kość - znakomity polski filozof prawa - postawił pytanie w czym leży bezpośrednia przyczyna motywującej siły prawa, która miarodajnie motywuje powszechne przestrzeganie prawa i daje szansę jego przeforsowania ${ }^{62}$. Odpowiedz na to pytanie znajdziemy w teorii uznania, czyli przyczyną jest tutaj uznanie prawa, które nie jest rozumiane jako pojedynczy akt psychiczny, lecz jako trwałe, habitualne zachowanie w sensie respektowania porządku prawnego ${ }^{63}$. Wobec tego można powiedzieć, że obowiązywanie prawa spoczywa na pozytywnym nastawieniu w stosunku do prawa, panującym we wspólnocie prawnej, w tym sensie, że wspólnota jako całość istniejące prawo aprobuje i uznaje je jako swoje ${ }^{64}$. Brak takiej aprobaty i uznania może niechybnie powodować negatywne nastawienie do niego i zakwestionowanie jego obowiązywania wyrażając się w formach jakie między innymi przedstawione zostały powyżej.

Grupy lub organizacje, które kwestionują legitymację zarówno ośrodka decyzji, jak i systemu norm ustanowionych przez niego zazwyczaj podejmują działania sprzeczne z tymi normami, mając przeświadczenie o wyższości własnego systemu norm, opartego na

\footnotetext{
${ }^{62}$ A. Kość, dz. cyt., s. 234.

63 TAMŻE, s. 234.

64 TAMŻE, s. 234.
} 
odmiennych podstawowych wartościach ${ }^{65}$. Zazwyczaj oznacza to konflikt wartości, którego rozwiązanie odbywa się niejednokrotnie za pomocą siły i przemocy ${ }^{66}$, a zwycięzca takiej rywalizacji ustanawia nowy lub zmieniony system norm prawnych powszechnie obowiązujących. Konstatując powyższe rozważania należy jednak pamietać, że ów zwycięzca, nie powinien nigdy w imię wartości przez siebie wyznawanych, dopuścić do ustanowienia norm oczywiście sprzecznych $z$ naturą osoby ludzkiej, oraz powinien podejmując każdorazową decyzję kaształtującą pozycję obywatela w państwie, uwzględniać dorobek narodów uznanych za cywilizowane w zakresie ochrony praw człowieka i obywatela i zasad ich kształtujących. W przeciwnym razie, nowo powstały system wartości i norm, może stać się podstawą do wynaturzeń o charakterze patologicznym i zbrodniczym, czego w historii świata ludzkość doświadczyła już wielokrotnie.

\section{Challenging the legitimacy of the law as a form of protection of the dignity of man and citizen}

This article is about the behavior patterns that challenge the legitimacy of the law. The analysis focuses on the basic forms of questioning the legitimacy of such rights namely the right to resistance, civil disobedience and revolution. The considerations made in this article are designed to synthetic analysis of the issues related to the questioning of state power by the citizens. The questions which are the subject of the following scientific reflection of an academic nature can be examined from the point of view of different branches of science. They are intensely analyzed on the ground of philosophy of history, political and economic history, political science, and many others. What seems obvious, in this paper emphasis is put on the subject of study of the law. The rights to resistance, civil disobedience and

\footnotetext{
${ }^{65} \mathrm{O}$ tym w jakiej mierze istnienie różnych grup społecznych narusza jednolitość naszej moralności pisze M. Ossowska, Podstawy nauki o moralności, Warszawa 1957, s. 347-372.

${ }^{66} \mathrm{Na}$ temat siły i przemocy jako atrybutów władzy państwowej, zob. M. KonARSKI, M. Woch, Siła i przemoc jako atrybut władzy państwowej, w: M. Konarski, M. Wielec, M. Woch (red.), dz. cyt., s. 93-122.
} 
revolution as forms of challenging the legitimacy of the law are insufficiently elaborated on in the science of the law and constitute a research area which few representatives of jurisprudence have the courage to step into. Typically, the aforementioned issues are raised in the science of the constitutional law however in a clearly insufficient way. For centuries, problems related to challenging the legitimacy of the law have been the subject of interest of the philosophy of the law and it is mainly there where we can find both questions and answers related to the binding force of the law as a system of norms of behaviour of particular importance. The following considerations are aimed at indicating basic theses to be coped with by a modern researcher focused on these socio-legal phenomena. Secondly, the following scientific reflections onto the forms of challenging the legitimacy of the law stimulate further research onto the area which should definitely be carried out due to its importance and nature, as well as meaning in the context of problems we face in modern times.

SŁOWA KLUCZOWE: człowiek, obywatel, godność, ochrona, osoba ludzka, prawa człowieka, prawo do oporu, nieposłuszeństwo.

KEYwORDs: human rights, forms of questioning the legitimacy of the law, right to resistance, civil disobedience, revolution

Nota o Autorze:

DR MARCIN KonARSKI - adiunkt w Katedrze Administracji Wydziału Nauk Społecznych i Administracji Wyższej Szkoły Menedżerskiej w Warszawie. Członek Komisji Prawniczej Polskiej Akademii Nauk Oddział w Lublinie. Autor publikacji z zakresu prawa cywilnego, prawa administracyjnego i polityki legislacyjnej. 